Care: Jurnal Ilmiah Ilmu Kesehatan Vol .7, No.2, 2019, hal 39-53

Tersedia online di https://jurnal.unitri.ac.id/index.php/care

ISSN 2527-8487 (online)

ISSN 2089-4503 (cetak)

\title{
ANALISIS KUALITAS PELAYANAN, SARANA PRASARANA DAN LINGKUNGAN TERHADAP KEPUASAN PASIEN
}

\author{
Sripina Ulandari ${ }^{1}$, Sunarsih Yudawati ${ }^{2}$ \\ ${ }^{1), 2)}$ Akademi Kebidanan Wira Husada Nusantara Malang \\ E-mail: vinawulandari98@yahoo.com; Sunarsihyudhawati@gmail.com
}

\begin{abstract}
The puskesmas must still be able to maintain the quality of services supported by adequate facilities and infrastructure and be supported by the creation of a clean, beautiful, neat and pleasant environment so as to meet the expectations or needs of patients. The purpose of this study was to analyze the relationship between the quality of services, facilities and the environment for patient satisfaction at Pujon Health Center Malang Regency. The type of research used is explanatory reset. The sampling technique used was purposive sampling. The sample in this study were patients who came to treatment (at least 2 times treatment) or patients who had used services to the Health Center as many as 150 respondents. Collecting data uses observation techniques, interviews, questionnaires and documentation. The data analysis used is multiple linear regression. Based on the results of the study prove the existence of a significant influence between the quality of service, infrastructure and environment on patient satisfaction in Health Center ( $p$-value $0.034<0.05$ ). The effect is positive and includes strong (correlation +0.910$)$, meaning that the higher the quality score of service, infrastructure and environment, the higher the patient satisfaction score and vice versa. These three elements influence customer satisfaction, so it is recommended that officers focus on these three things as a strategy to satisfy customers and it is expected that the internal audit team regularly evaluates the three matters and is evaluated regularly.
\end{abstract}

Keywords: Service Quality; Infrastructure and Environment Facilities; Patient Satisfaction.

\begin{abstract}
ABSTRAK
Puskesmas harus dapat menjaga kualitas pelayanan ditunjang dengan sarana dan prasarana yang memadai serta didukung dengan penciptaan lingkungan yang bersih, indah, rapi dan menyenangkan sehingga dapat memenuhi harapan atau kebutuhan pasien yang pada akhirnya dapat memberikankepuasan kepada pasien.Tujuan dari penelitian ini adalah untuk menganalisis hubungan kualitas pelayanan, sarana prasarana dan lingkungan atas kepuasan pasien di Puskesmas Pujon Kabupaten Malang.Jenis penelitian yang digunakan yaitu explanatory reset. Tehnik sampling yang digunakan adalah purposive sampling.Sampel dalam penelitian ini adalah pasien yang datang berobat (minimal 2 kali berobat) atau pasien yang pernah menggunakan jasa pelayanan ke Puskesmas yaitu sebanyak 150 responden. Pengumpulan data menggunakan tehnik observasi, wawancara, kuesioner dan dokumentasi. Analisis data yang dipergunakan adalah dengan regresi linier berganda. Berdasarkan hasil penelitian membuktikan

Cara mengutip: Ulandari, Sripina \& Yudawati, Sunarsih. (2019). Analisis Kualitas pelayanan, Sarana Prasarana dan Lingkungan Terhadap Kepuasan Pasien. Care:Jurnal Ilmiah Ilmu Kesehatan, 7(2), 39-53


adanya pengaruh yang signifikan antara kualitas pelayanan, sarana prasarana dan lingkungan terhadap kepuasan pasien di Puskesmas ( $p$ value $0,034<0,05$ ). Pengaruhnya bersifat positif dan termasuk kuat (correlation +0.910$)$, artinya semakin tinggi skor kualitas pelayanan, sarana prasarana dan lingkungan maka semakin tinggi skor kepuasan pasien dan sebaliknya.Ketiga elemen tersebut berpengaruh terhadap kepuasan pelanggan, sehingga disarankan agar petugas memfokuskan kepada ketiga hal tersebut sebagai strateginya untuk memuaskan pelanggan dan diharapkan tim audit internal secara berkala melakukan penilaian terhadap ketiga hal dan dievaluasi secara berkala.

Kata Kunci : Kualitas Pelayanan; SaranaPrasarana dan Lingkungan; Kepuasan Pasien.

\section{PENDAHULUAN}

Puskesmas sebagai unit pelaksanan teknis wilayah Dinas Kesehatan Kabupaten/Kota bertanggungjawab untuk menyelenggarakan pembangunan kesehatan di wilayah kerjanya.Agar dapat melaksanakan fungsinya dengan baik maka puskesmas tetap harus dapat menjaga kualitas pelayanan ditunjang dengan sarana dan prasarana yang memadai serta didukung dengan penciptaan lingkungan yang bersih, indah, rapi dan menyenangkan sehingga dapat memenuhi harapan atau kebutuhan pasien yang pada akhirnya dapat memberikankepuasan kepada pasien. Hal ini sesuai dengan teorinya Kotler (2000) yang menjelaskan bahwa kepuasan adalah perasaan seseorang setelah membandingkan kinerja atau hasil yang dirasakan dibandingkan dengan harapannya.

Dalam memberikan pelayanan yang berkualitas, Puskesmas masih mempunyai beberapa kendala yang sering dikeluhkan oleh sebagian besar pasien, yaitu: standar waktu pelayanan, kecepatan pelayanan, ketersediaan fasilitas ruang tunggu yang terbatas, kurangnya jumlah petugas.Alasanalasan tersebut tentunya menambah anggapan buruk oleh masyarakat tentang pelayanan yang mereka dapatkan di Puskesmas, karena seharusnya Puskesmas sebagai pemberi layanan kesehatan terdekat masyarakat yang dianggap dapat membantu dalam memberikan pertolongan pertama yang sesuai dengan standar pelayanan kesehatan dasar. Itulah mengapa seringkali masyarakat beranggapan kurang puas terhadap penyelenggaraan pelayanan kesehatan di Puskesmas karena pelayanan pada Puskesmas.

Hasil studi pendahuluan di puskesmas Kasembon dari 10 pasien yang dilakukan wawancara mengatakan 5 pasien $(50 \%)$ sangat puas, 2 pasien (20\%) cukup puas dan 3 pasien (30\%) kurang puas. Hasil ini memberikan gambaran bahwa masih ada pasien yang belum puas terhadap pelayanan yang diberikan. Dari studi pendahuluan 
didapatkan masih adanya pasien puskesmas yang belum puas karena berbagai faktor. Diketahui bahwa lingkungan puskesmas masih kurang memenuhi standar. Terlihat bahwa halaman masih sedikit kurang bersih, kondisi tempat antri di loket juga kurang didukung dengan tempat yang nyaman, kursi juga terlihat masih kurang sehingga ada pasien yang berdiri, halaman juga belum semua di pasang paving, penghijauan juga terasa masih kurang, rasa sejuk juga masih kurang karena tidak ada suasana air misalnya kolam juga belum ada, taman ada namun belum maksimal dalam pengaturannya, tempat parkir sudah ada akan tetapi belum permanent dan mencukupi untuk parkir semua kendaraan pengunjung. Kondisi ini jelas berpengaruh terhadap kepuasan pasien.

Dampak lebih lanjut dari ketidakpuasan pasien adalah pasien enggan datang lagi, akhirnya angka kunjungan pasien rendah yang pada tahap selanjutnya adalah puskesmas akan kehilangan pasien. Kepuasan menurut Kotler (2000) adalah perasaan senang atau tidak kecewa dari seseorang sebagai hasil dari membandingkan antara produk yang dirasakan dengan yang diharapkan. Jika puskesmas tidak mampu memberikan kepuasan terhadap pasien maka puskesmas akan ditinggalkan oleh pasien.
Oleh karena itu harus ada strategi untuk meningkatkan mutu pelayanan. Pada saat ini puskesmas sudah mulai melangkah untuk meningkatkan mutu pelayanan ke jenjang lebih baik dengan mengikuti penilaian sesuai standar Akreditasi Puskesmas. Disadari bahwa nilai Akreditasi suatu Puskesmas pada saat ini seakan sudah menjadi kebutuhan bagi institusi yang memberikan pelayanan langsung kepada masyarakat, termasuk pelayanan kesehatan public.

Demikian juga dengan Puskesmas Pujon Kabupaten Malang pada saat ini merupakan puskesmas yang sudah mempunyai Akreditasi Puskesmas. Oleh karena itu selalu berorientasi pada kepuasan pasien karena nilai Akreditasi Puskesmas merupakan suatu bentuk pengakuan terhadap hasil dari suatu proses penilaian standar yang komprehensif bagi perusahaan pelayanan jasa seperti puskesmas. Oleh karena itu Puskesmas Pujon Kabupaten Malang juga harus selalu meningkatkan mutu jasa pelayanan, sarana prasarana serta lingkungan yang mendukung agar supaya dapat memberikan kepuasan kepada pelanggan. Harapan ini layak disandarkan kepada Akreditasi Puskesmas karena melalui standar ini pada umumnya puskesmas akan memperoleh nilai lebih baik, sehingga tingkat kesadaran menjaga kualitas, prosedur dan tanggung jawab lebih 
jelas dan terdokumentasi dengan baik, menghilangkan pekerjaan yang tidak perlu, lebih mudah ditelusuri dan dilakukan audit, pelayanan lebih baik, meningkatkan kepuasan pelanggan serta karyawan, peningkatan yang berkesinambungan, meningkatkan keuntungan, kesempatan ekspansi, meningkatkan mutu serta merubah image buruk masyarakat terhadap pelayanan kesehatan pemerintah.

Meskipun demikian apakah dengan memiliki standar mutu pelayanan dengan telah terakreditasinya puskesmas, kebutuhan konsumen pada pelayanan yang diberikan Puskesmas Pujon Kabupaten Malang sudah sesuai dengan harapan pasien dan apakah kepuasan pasien sudah terpenuhi? Oleh karena itu dalam hal ini peneliti tertarik untuk melakukan penelitian guna mengetahui kepuasan pasien melalui penilaian kualitas pelayanan, sarana prasarana dan lingkungan yang diberikan. Langkah pertama yang dilakukan oleh peneliti adalah mengetahui dimensi kualitas pelayanan, sarana prasarana dan lingkungan yang mempengaruhi kepuasan pasien di Puskesmas Pujon Kabupaten Malang. Untuk itu dapat menentukan kebijakan pelayanan yang tepat, khususnya dalam pelayanan kepada pasien, diperlukan kajian tentang dimensi kualitas pelayanan.
Sehubungan dengan hal itu, permasalahannya adalah apakah ada pengaruh variabel kualitas pelayanan, sarana prasarana dan lingkungan terhadap kepuasan pasien. Penelitian ini perlu dilakukan dalam rangka memberikan manfaat sebagai sumbangan pemikiran kepada instansi pemerintah penyedia layanan kesehatan dalam upaya peningkatan pelayanan kepada pasien, memberikan pertimbangan bagi pihak manajemen dalam pengambilan keputusan tentang hubungan perbaikan kinerja pelayana di Puskesmas Pujon Kabupaten Malang.

Berdasarkan uraian pada latar belakang di atas, maka peneliti tertarik untuk melakukan penelitian yang berjudul "Analisis kualitas pelayanan, sarana prasarana dan lingkungan terhadap kepuasan pasien di Puskesmas Pujon di Kabupaten Malang”.

\section{METODE PENELITIAN}

Dalam penelitian ini menggunakan jenis penelitian explanatory reset. Penelitian ini merupakan tipe penelitian yang mengalisis pengaruh antar variabel. Variabel yang dikembangkan dalam penelitian ini meliputi variable bebas yaitu pengaruh antara kualitas pelayanan, sarana prasarana dan lingkungan sedangkan variable terikatnya adalah kepuasan pasien di Puskesmas Pujon Kabupaten Malang. Penelitian ini 
Care: Jurnal Ilmiah Ilmu Kesehatan Vol .7, No.2, 2019, hal 39-53

dilaksanakan di Puskesmas Pujon Kecamatan Pujon Kecamatan Pujon Kabupaten Malang pada bulan Mei 2018 sampai dengan Agustus 2018. Pada penelitian ini variabel independen adalah kualitas pelayanan (X1), sarana prasarana (X2) dan lingkungan puskesmas (X3), sedangkan variabel terikat adalah Kepuasan Pasien (Y).

Populasi pada penelitian ini adalah semua obyek yang ada di Puskesmas Pujon Kecamatan Pujon Kabupaten Malang dan pasien yang datang berobat ke Puskesmas Pujon Kabupaten Malang yaitu sebenyak 325 orang. Tehnik Sampling yang digunakan dalam penelitian ini adalah purposive sampling. Sampel dalam penelitian ini adalah pasien yang datang berobat (minimal 2 kali berobat) atau pasien yang pernah menggunakan jasa pelayanan ke Puskesmas Pujon Kecamatan Pujon Kabupaten Malang yaitu sebanyak 150 responden.

Pengumpulan data di lakukan setelah dilakukan dengan memberikan kuisioner, melakukan observasi, wawancara dan pendokumentasian. Analisis data yang akan digunakan dalam penelitian ini adalah teknik analisis asosiatif yaitu suatu teknik analisis yang hanya bertujuan untuk mengetahui hubungan satu variabel terhadap variabel yang lain. Dalam penelitian ini analisis pengaruh kualitas pelayanan, sarana prasarana dan lingkungan terhadap kepuasan pasien di Puskesmas Pujon Kabupaten Malangdianalisis dengan menggunakan uji statistik regresi linier berganda menggunakan program SPSS 17

\section{HASIL}

Tabel 1. Hasil Analisis Regresi Linier Pengaruh yang Signifikan antara Kualitas Pelayanan terhadap Kepuasan Pasien di Puskesmas Pujon Kabupaten Malang

\begin{tabular}{lcccl}
\hline Komponen & $\begin{array}{c}\mathrm{T}_{\text {hitun }} \\
\mathrm{g}\end{array}$ & Sig & $\alpha$ & Ket \\
\hline $\begin{array}{l}\text { Kualitas } \\
\text { pelayanan- }\end{array}$ & 3,137 & 0.002 & 0,05 & $\begin{array}{l}\text { Ho } \\
\text { Kepuasan }\end{array}$ \\
Pasien & & & & ditolak \\
$\mathrm{N}=150$ & & & & \\
$\alpha=0,05$ & & & & \\
\hline
\end{tabular}

Berdasarkan Tabel 1 diketahui ada pengaruh yang signifikan antara kualitas pelayanan terhadap kepuasan pasien di Puskesmas Pujon Kabupaten Malang ( $p$ value $0,002<0,05$ maka $\mathrm{Ho}$ ditolak) Pengaruhnya bersifat positif dan termasuk kuat (correlation +0.566$)$, artinya semakin tinggi skor kualitas pelayanan maka semakin tinggi skor kepuasan pasien dan sebaliknya. Probabilitasnya dapat dirumuskan dalam persamaan $y=a+b 1 x 1$ atau $y=20,611+$ $0,174 \mathrm{X}_{1}$

Berdasarkan Tabel 2 diketahui bahwa ada pengaruh yang signifikan antara sarana 
prasarana terhadap kepuasan pasien di Puskesmas Pujon Kabupaten Malang ( $p$ value $0,034<0,05$ maka Ho ditolak). Pengaruhnya bersifat positif dan termasuk kuat (correlation +0.905$)$, artinya semakin tinggi skor sarana prasarana maka semakin tinggi skor kepuasan pasien dan sebaliknya. Probabilitasnya dapat dirumuskan dalam persamaan $y=a+b 2 x 2$ atau $y=20,611+$ $0,784 \mathrm{X}_{2}$.

Tabel 2. Hasil Analisis Regresi Linier Pengaruh yang Signifikan antara Sarana Prasarana terhadap Kepuasan Pasien di Puskesmas Pujon Kabupaten Malang

\begin{tabular}{llccc}
\hline Komponen & $\mathbf{T}_{\text {hitung }}$ & Sig & $\boldsymbol{\alpha}$ & Ket \\
\hline Sarana & 2,135 & 0.034 & 0,05 & Ho \\
prasarana- & & & & ditolak \\
Kepuasan & & & & \\
Pasien & & & & \\
$\mathrm{N}=150$ & & & & \\
$\alpha=0,05$ & & & & \\
\hline
\end{tabular}

Tabel 3. Hasil Analisis Regresi Linier Pengaruh yang Signifikan antara Lingkungan terhadap Kepuasan Pasien di Puskesmas Pujon Kabupaten Malang

\begin{tabular}{lcccl}
\hline Komponen & $\mathrm{T}_{\text {hitung }}$ & Sig & $\alpha$ & \multicolumn{1}{c}{ Ket } \\
\hline Lingkungan & 3,509 & 0.001 & 0,05 & Ho \\
- Kepuasan & & & & ditolak \\
Pasien & & & & \\
$\mathrm{N}=150$ & & & & \\
$\alpha=0,05$ & & & & \\
\hline
\end{tabular}

Berdasarkan Tabel 3 diketahui ada pengaruh yang signifikan antara lingkungan terhadap kepuasan pasien di Puskesmas Pujon Kabupaten Malang ( $\phi$ value $0,034<$ 0,05 maka Ho ditolak). Pengaruhnya bersifat positif dan termasuk kuat (correlation
+ 0.910), artinya semakin tinggi skor lingkungan maka semakin tinggi skor kepuasan pasien dan sebaliknya. Probabilitasnya dapat dirumuskan dalam persamaan $\mathrm{y}=\mathrm{a}+\mathrm{b} 3 \mathrm{x} 3$ atau $\mathrm{y}=20,611+$ $1,260 \mathrm{X}_{3}$.

Tabel 4. Pengaruh Secara Simultan Kualitas Pelayanan, Sarana dan Prasarana Serta Lingkungan terhadap Kepusan Pasien

\begin{tabular}{lcccc}
\hline Komponen & $\mathbf{T}_{\text {hitung }}$ & Sig & $\boldsymbol{\alpha}$ & \multicolumn{1}{c}{ Ket } \\
\hline Kualitas & 16,367 & 0.000 & 0,05 & Ho \\
pelayanan, & & & & ditolak \\
sarana dan & & & & \\
prasarana & & & & \\
serta & & & & \\
lingkungan- & & & & \\
Kepuasan & & & & \\
Pasien & & & & \\
$\mathrm{N}=150$ & & & & \\
$\alpha=0,05$ & & & & \\
\hline
\end{tabular}

Berdasarkan Tabel 4 diketahui bahwa ada pengaruh yang signifikan antara kualitas pelayanan, sarana prasarana dan lingkungan terhadap kepuasan pasien di Puskesmas Pujon Kabupaten Malang ( $p$ value 0,034 < 0,05 maka Ho ditolak). Pengaruhnya bersifat positif dan termasuk kuat (correlation + 0.910), artinya semakin tinggi skor kualitas pelayanan, sarana prasarana dan lingkungan maka semakin tinggi skor kepuasan pasien dan sebaliknya. Probabilitasnya dapat dirumuskan dalam persamaan $\mathrm{y}=\mathrm{a}+\mathrm{b} 1 \mathrm{x} 1+\mathrm{b} 2 \mathrm{x} 2+\mathrm{b} 3 \mathrm{x} 3$ atau $\mathrm{y}=20,611++0,174 \mathrm{X}_{1}+0,784 \mathrm{X}_{2}+$ $1,260 \mathrm{X}_{3}$. 


\section{PEMBAHASAN}

\section{Pengaruh antara Kualitas Pelayanan terhadap Kepuasan Pasien}

Berdasarkan hasil diketahui pengaruh antara kualitas pelayanan terhadap kepuasan pasien di Puskesmas Pujon Kabupaten Malang sebesar 32\% ( $R$ square Linear 0,32). Berdasarkan Tabel diketahui ada pengaruh yang signifikan antara kualitas pelayanan terhadap kepuasan pasien di Puskesmas Pujon Kabupaten Malang ( $p$ value 0,002 < 0,05 maka Ho ditolak). Pengaruhnya bersifat positif dan termasuk kuat (correlation + 0.565), artinya semakin tinggi skor kualitas pelayanan maka semakin tinggi skor kepuasan pasien dan sebaliknya. Probabilitasnya dapat dirumuskan dalam persamaan $y=a+b 1 x 1$ atau $y=20,611+$ $0,174 \mathrm{X}_{1}$.

Kepuasan atau ketidakpuasan pelanggan adalah respon pelanggan terhadap evaluasi ketidaksesuaian atau dikonfirmasikan yang disesuaikan antara harapan sebelumnya (norma kinerja lainnya) dan kinerja aktual produk yang dirasakan setelah pemakaiannya. Mengacu pada definisi ini maka kepuasan passien dapat dipengaruhi oleh penilaiannya mengenai kualitas produk atau jasa yang diharapkan (Tjiptono, 2005).

Berkaitan dengan pendapat di atas, jika hasil penelitian menunjukkan pengaruh kualitas pelayanan terhadap kepuasan pasien di Puskesmas Pujon Kabupaten Malang sebesar 32\%, maka hal ini dapat diinterpretasikan bahwa peran kualitas pelayanan untuk dapat memuaskan pelanggannya juga perlu diperhatikan karena memberikan kontribusi sebesar 32\% mengingat masih banyak hal lain yang berperan di dalam menciptakan kepuasan pelanggan. Hal ini juga sesuai dengan pendapat para ahli sebelumnya yang menyatakan bahwa kualitas itu pada dasarnya merupakan hal apapun yang menjadi kebutuhan dan keinginan konsumen. Kebutuhan dan keinginan ini harus dipenuhi oleh pemberi pelayanan jika mengharapkan pasien akan terpuaskan karena pada prinsipnya kepuasan akan tercipta makanaka produsen bisa memenuhi atau memberikan lebih dari apa yang diharapkan atau dibutuhkan pelanggannya.

Hasil analisis lebih lanjut membuktikan adanya pengaruh yang signifikan antara kualitas pelayanan terhadap kepuasan pasien di Puskesmas Pujon Kabupaten Malang ( $\not$ value $0,002<0,05$ maka Ho ditolak). Hal ini disebabkan karena kualitas pelayanan mengandung unsur kesempurnaan atas kemampuannya (availability), kinerja (performance), kendalannya (reliability), kemudahan pemeliharaan (maintainability) yang semuanya sangat diharapkan dan 
dibutuhkan pelanggan atau pasien. Jika petugas memiliki kemampuan sangat baik, kinerjanya juga sangat baik, dapat diandalkan dalam menangani pelanggannya, dan kemudahan di dalam memberikan pelayanan, maka hal ini akan memenuhi harapan dan kebutuhan pelanggannya, sehingga pelanggan atau pasien terpuaskan. Jika yang terjadi sebaliknya maka pelanggan atau pasien pasti tidak akan terpuaskan. Jadi secara prinsip kualitas pelayanan mutlak harus diciptakan manakala ingin memuaskan pelanggannya.

Hasil analisis juga menunjukkan bahwa pengaruhnya bersifat positif dan termasuk kuat (correlation +0.565$)$, artinya semakin tinggi skor kualitas pelayanan maka semakin tinggi skor kepuasan pasien dan sebaliknya. Hal ini disebabkan untuk terciptanya perasaan puas mau tidak mau pemberi pelayanan harus memenuhi terlebih dahulu berbagai dimensi yang dapat memuaskan pelangganya dari aspek mutu atau kualitas pelayanan, seperti menunjukkan kemampuannya yang baik, menunjukkan pelayanan yang dapat diandalkan, menunjukkan sistem pelayanan yangmudah dan tidak berbelit-belit, pelayanan yang cepat, pelayanan yang ramah, pelayanan yang penuh empati kepada setiap papsien yang semuanya menjadi unsur keinginan dan kebutuhan pasien. Pengaruhnya termasuk kuat dalam arti jika dimensi kualitas pelayanan tersebut tidak dapat terpenuhi maka mustahil pasien akan terpuaskan. Artinya dimensi kualitas pelayanan tersebut mutlak perlu diwujudkan oleh petugas jika mengharapkan pasien terpuaskan.

Secara matematik nilai probabilitas kualitas pelayanan dapat memuaskan pasien dapat dirumuskan sebagai berikut y $=20,611+$ $0,174 \mathrm{X}_{1}$. Artinya jika skor kualitas pelayanan ditingkatkan misalnya diberikan skor 1 maka probability untuk meningkatkan skor kepuasan pelanggan sebesar y $=20,611+$ 0,174 (1) atau y $=20,785$, jika skor kualitas pelayanan ditingkatkan menjadi skor 2 maka probability untuk meningkatkan skor kepuasan pelanggan sebesar $\mathrm{y}=20,611+$ 0,174 (2) atau y $=20,959$ dan seterusnya.

Hasil penelitian ini sejalan dengan penelitian Rahmulyono (2008) yang menunjukkan adanya pengaruh bersama pelayanan dimensi Reliability (X1), Responsiveness (X2), Assurance (X3), Empatby (X4) dan Tangible (X5) terhadap kepuasan pasien (Y) dijelaskan oleh $\mathrm{R}^{2}$ atau determinasi. Pada hasil diketahui sebesar 0.464 atau $46.4 \%$ ( $\mathrm{R}^{2} \times 100 \%$ ), sisanya sebesar $53.6 \%(100 \%-$ $46.4 \%$ ) dipengaruhi oleh variabel selain dimensi tersebut. Nilai Fhitung (16.287) lebih besar dibandingkan F-tabel (2.311) 
sehingga berada di daerah terdapat pengaruh atau signifikan maka hipotesis nihil ( Ho ) ditolak dan hipotesis alternatif ( Ha ) diterima. Artinya, variabel reliability, responsiveness, assurance, empatby dan tangible secara bersama-sama mempengaruhi variabel kepuasan pasien Puskesmas Depok I Sleman secara signifikan.

\section{Pengaruh Sarana dan Prasarana terhadap Kepuasan Pasien}

Berdasarkan data diketahui pengaruh sarana prasarana terhadap kepuasan pasien di Puskesmas Pujon Kecamatan Pujon Kabupaten Malang sebesar 81,9\% ( $R$ square Linear 0,819). Berdasarkan tabel diketahui ada pengaruh yang signifikan antara sarana prasarana terhadap kepuasan pasien di Puskesmas Pujon Kabupaten Malang ( $p$ value $0,034<0,05$ maka Ho ditolak). Pengaruhnya bersifat positif dan termasuk kuat (correlation +0.905$)$, artinya semakin tinggi skor sarana prasarana maka semakin tinggi skor kepuasan pasien dan sebaliknya. Probabilitasnya dapat dirumuskan dalam persamaan $y=a+b 2 x 2$ atau $y=20,611+$ $0,784 \mathrm{X}_{2}$.

Kotler (2000) mendefinisikan kepuasan adalah sebagai tingkat perasaan seseorang setelah membandingkan antara kinerja atau hasil yang dirasakan dibandingkan dengan harapannya. Untuk itu dalam rangka mencapai tingkat kepuasan pasien maka puskesmas harus ditunjang dengan sarana dan prasarana yang baik seperti tempat pelayanan kesehatan ditata rapi dan bersih, dan ber-AC, sehingga memberi kenyamanan pada pasien dan tenaga kesehatan yang melayaninya. Ruang tunggu pasien ditata rapi dan bersih serta dilengkapai dengan sarana hiburan yang sesuai dengan harapan pasien. Kamar mandi dan WC bersih, tidak berbau dan cukup air, serta dibersihkan setiap hari (Dinas Kesehatan Kabupaten Jombang, 2010).

Berkaitan dengan hal tersebut maka jika hasil penelitian menunjukkan hubungan sarana prasarana terhadap kepuasan pasien di Puskesmas Pujon Kabupaten Malang sebesar 81,9\%, hal ini disebabkan sarana prasarana yang baik merupakan wujud nyata yang langsung dapat dilihat dan dirasakan pasien atau pelanggan, sehingga dengan cepat dapat menilai bahwa sarana dan prasarana yang disediakan sudah memenuhi harapan atau keinginan dan kebutuhannya atau belum. Ketika keberadaan sarana dan prasarana memenuhi harapannya maka saat itu juga langsung memberikan penilaian positif dan langsung terpuaskan. Jika yang terjadi sebaliknya maka pasien atau pelanggan langsung kecewa dan merasa tidak puas terhadap pelayanan yang 
diberikan. Oleh karenanya proporsi sarana dan prasarana untuk dapat mewujudkan kepuasan pelanggan juga sangat tinggi.

Hasil analisis lebih lanjut menunjukkan ada pengaruh yang signifikan antara sarana prasarana terhadap kepuasan pasien di Puskesmas Pujon Kabupaten Malang ( $\phi$ value $0,034<0,05$ maka Ho ditolak). Hal ini disebabkan sarana prasarana merupakan dimensi kualitas pelayanan dari unsur keberwujudan, yakni wujud fisik yang langsung dapat dilihat, diraba, dirasakan oleh semua pelanggan. Ketika sarana dan prasarana yang disediakan kurang, atau ada tetapi tidak tertata dengan rapi, tidak bersih, tidak indah, maka pasien secara langsung dapat melihat, mencermati, menilai sarana dan prasarana yang disediakan kurang baik sehingga pasien langsung kecewa atau tidak terpuaskan.

Hasil analisis juga menunjukkan bahwa pengaruhnya bersifat positif dan termasuk kuat (correlation +0.905$)$, artinya semakin tinggi skor sarana prasarana maka semakin tinggi skor kepuasan pasien dan sebaliknya. Hal ini disebabkan untuk terciptanya perasaan puas mau tidak mau pemberi pelayanan harus memenuhi terlebih dahulu berbagai sarana dan prasarana di tempat pelayanan yang baik, lengkap, tertata rapi, bersih, indah karena unsur ini dapat dilihat secara langsung oleh semua pelanggan. Pengaruhnya termasuk kuat dalam arti jika sarana dan prasarana tersebut tidak tersedia dengan baik, bersih, rapi, indah maka mustahil pasien akan terpuaskan. Artinya keberadaan sarana dan prasarana di tempat pelayanan tersebut mutlak perlu diwujudkan oleh petugas jika mengharapkan pasien terpuaskan.

Secara matematik nilai probabilitas sarana dan prasarana dapat memuaskan pasien dapat dirumuskan sebagai berikut y y $=\mathrm{a}+$ $\mathrm{b} 2 \mathrm{x} 2$ atau $\mathrm{y}=20,611+0,784 \mathrm{X}_{2}$. Artinya jika skor sarana dan prasarana ditingkatkan misalnya diberikan skor 1 maka probability untuk meningkatkan skor kepuasan pelanggan sebesar y $=20,611+0,784$ (1) atau $\mathrm{y}=21.395$, jika skor sarana dan prasarana ditingkatkan menjadi skor 2 maka probability untuk meningkatkan skor kepuasan pelanggan sebesar y $=20,611+$ 0,784 (2) atau y $=22,179$ dan seterusnya.

\section{Pengaruh Lingkungan terhadap Kepuasan Pasien}

Berdasarkan data diketahui pengaruh lingkungan terhadap kepuasan pasien di Puskesmas Pujon Kabupaten Malang sebesar 82,9\% ( $R$ square Linear 0,829). Berdasarkan tabel 4.10 diketahui ada pengaruh yang signifikan antara lingkungan terhadap kepuasan pasien di Puskesmas 
Pujon Kabupaten Malang ( $p$ value 0,034 < 0,05 maka Ho ditolak). Pengaruhnya bersifat positif dan termasuk kuat (correlation + 0.910), artinya semakin tinggi skor lingkungan maka semakin tinggi skor kepuasan pasien dan sebaliknya. Probabilitasnya dapat dirumuskan dalam persamaan $y=a+b 3 x 3$ atau $y=20,611+$ $1,260 \mathrm{X}_{3}$.

Lingkungan puskesmas adalah berbagai komponen penunjnag puskesmas seperti taman, tempat parkir, ruang tunggu dan berbagai tempat lainnya. Agar dapat menunjang pelayanan yang bermutu sehingga dapat memberikan kepuasan pada pasien maka lingkungan puskesmas harus dibuat taman yang membuat suasana asri dan segar (Dinas Kesehatan Kabupaten Jombang, 2010).

Berkaitan dengan hal tersebut maka jika hasil penelitian menunjukkan pengaruh lingkungan terhadap kepuasan pasien di Puskesmas Pujon Kabupaten Malang sebesar $82,9 \%$ ( $R$ square Linear 0,829 ), hal ini disebabkan lingkungan yang baik merupakan wujud nyata yang langsung dapat dilihat dan dirasakan pasien atau pelanggan, sehingga dengan cepat dapat menilai bahwa lingkungan yang ada sudah memenuhi harapan atau keinginan dan kebutuhannya atau belum. Ketika keberadaan lingkungan memenuhi harapannya maka saat itu juga pelanggan langsung memberikan penilaian positif dan langsung terpuaskan. Jika yang terjadi sebaliknya maka pasien atau pelanggan akan merasa langsung kecewa dan merasa tidak terpuaskan terhadap keeberadaan unit pelayanan yang ada. Oleh karenanya proporsi lingkungan untuk dapat mewujudkan kepuasan pelanggan juga sangat tinggi.

Hasil analisis lebih lanjut menunjukkan ada pengaruh yang signifikan antara lingkungan terhadap kepuasan pasien di Puskesmas Pujon Kabupaten Malang ( $\phi$ value 0,034 < 0,05 maka Ho ditolak). Hal ini disebabkan lingkungan merupakan salah dimensi kualitas pelayanan dari unsur keberwujudan, yakni wujud fisik yang langsung dapat dilihat, diraba, dirasakan oleh semua pelanggan. Ketika lingkungan yang disediakan kurang baik, kurang rapi, kurang indah, kurang menarik atau ada tetapi tidak tertata dengan rapi, tidak bersih, tidak indah, maka pasien secara langsung dapat melihat, mencermati, menilai bahwa keberdaan lingkungan secara umum kurang baik sehingga pasien merasa kurang nyaman dan tidak terpuaskan.

Hasil analisis juga menunjukkan bahwa pengaruhnya bersifat positif dan termasuk 
kuat (correlation +0.910$)$, artinya semakin tinggi skor lingkungan maka semakin tinggi skor kepuasan pasien dan sebaliknya. Hal ini disebabkan untuk terciptanya perasaan puas mau tidak mau pemberi pelayanan harus memenuhi terlebih dahulu berbagai unsur keberwujudan yang salah satunya adalah lingkungan di tempat pelayanan yakni lingkungan yang baik, tertata rapi, bersih, indah dan menarik karena unsur ini dapat dilihat secara langsung oleh semua pelanggan. Pengaruhnya termasuk kuat dalam arti jika lingkungan tersebut tidak tersedia dengan baik, bersih, rapi, indah dan menarik maka mustahil pasien akan terpuaskan. Artinya keberadaan lingkungan di tempat pelayanan tersebut mutlak perlu diwujudkan oleh petugas jika mengharapkan pasien terpuaskan.

Secara matematik nilai probabilitas lingkungan dapat memuaskan pasien dapat dirumuskan sebagai berikut $\mathrm{y}=\mathrm{a}+\mathrm{b} 3 \mathrm{x} 3$ atau $y=20,611+1,260 X_{3}$. Artinya jika skor lingkungan ditingkatkan misalnya diberikan skor 1 maka probability untuk meningkatkan skor kepuasan pelanggan sebesar $\mathrm{y}=20,611+0,784(1)$ atau $\mathrm{y}=$ 21.817, jika skor lingkungan ditingkatkan menjadi skor 2 maka probability untuk meningkatkan skor kepuasan pelanggan sebesar $\mathrm{y}=20,611+0,784(2)$ atau $\mathrm{y}=$ 23.023 dan seterusnya.

\section{Pengaruh Secara Simultan Kualitas Pelayanan, Sarana dan Prasarana Serta Lingkungan terhadap Kepusan Pasien}

Berdasarkan data diketahui ada pengaruh yang signifikan antara kualitas pelayanan, sarana prasarana dan lingkungan terhadap kepuasan pasien di Puskesmas Pujon Kabupaten Malang ( $p$ value 0,034 < 0,05 maka Ho ditolak). Pengaruhnya bersifat positif dan termasuk kuat (correlation + 0.910), artinya semakin tinggi skor kualitas pelayanan, sarana prasarana dan lingkungan maka semakin tinggi skor kepuasan pasien dan sebaliknya. Probabilitasnya dapat dirumuskan dalam persamaan $\mathrm{y}=\mathrm{a}+\mathrm{b} 1 \mathrm{x} 1$ + b2x2 + b3x3 atau $y=20,611++$ $0,174 \mathrm{X}_{1}+0,784 \mathrm{X}_{2}+1,260 \mathrm{X}_{3}$

Berdasarkan berbagai definisi tentang kepuasan oleh para ahli dapat diarik suatu kesamaan yaitu kepuasan itu menyangkut komponen kepuasan atau harapan dari kinerja. Umumnya harapan pelanggan merupakan perkiraan atau keyakinan pelanggan tentang apa yang akan diterimanya bila ia membeli atau mengkonsumsi suatu produk, sedang kinerja yang dirasakan adalah persepsi pelanggan terhadap apa yang ia terima setelah mengkonsumsi produk yang dibeli. Dalam hal ini termasuk harapan mengenai kualitas pelayanan, sarana dan prasarana yang disediakan serta keberwujudan 
Care: Jurnal Ilmiah Ilmu Kesehatan Vol .7, No.2, 2019, hal 39-53

lingkungan tempat pelayanan. Oleh karenanya kepuasan pelanggan dipengaruhi oleh faktor terpenuhi atau tidak terpenuhinya harapan pelanggan terhadap keterandalan, kesigapan, jaminan, empati dan sifat nyata dari pelayanan yang diterima.

Adanya pengaruh yang signifikan antara kualitas pelayanan, sarana prasarana dan lingkungan terhadap kepuasan pasien disebabkan ketiga variabel tersebut merupakan unsur atau dimensi kualitas pelayanan yang menjadi faktor penentu kepuasan pelanggan. Kualitas menyangkut mutu yang pekerjaan yang telah dikerjakan yang harus ditunjang oleh keberadaan sarana dan prasarana yang memadadi dengan di dukung oleh kondisi lingkungan tempat pelayanan yang baik, lengkap, rapi, indah dan menarik. Dalam hal ini mencerminkan pengukuran tingkat kepuasan pasien terhadap pelayanan yang diberikan oleh pihak pemberi pelayanan yang ditunjang dengan kelengpan sarana dan prasarana serta lingkungan tempat pelayanan yang baik. Sebagai instansi yang berhadapan langsung dengan masyarakat (pasien) maka puskesmas harus mampu memuaskan masyarakat pengunjungnya.

Pengaruhnya bersifat positif dan termasuk kuat (correlation +0.910$)$, artinya semakin tinggi skor kualitas pelayanan, sarana prasarana dan lingkungan maka semakin tinggi skor kepuasan pasien dan sebaliknya. Hal ini disebabkan untuk terciptanya perasaan puas mau tidak mau pemberi pelayanan harus memenuhi terlebih dahulu berbagai unsur termasuk dimensi kualitas pelayanan, keberwujudan sarana dan prasarana tempat pelayanan serta di dukung kondisi lingkungan di tempat pelayanan yang baik, tertata rapi, bersih, indah dan menarik karena unsur ini dapat dilihat secara langsung oleh semua pelanggan. Pengaruhnya termasuk kuat dalam arti jika ketiga variabel tersebut tidak terpenuhi, kualitas pelayanan dinilai jelek, sarana dan prasarana dinilai jelek, lingkungan dinilai tidak tersedia dengan baik, bersih, rapi, indah dan menarik maka mustahil pasien akan terpuaskan. Artinya keberadaan ketiga variabel tersebut di tempat pelayanan mutlak perlu diwujudkan secara bersama sama oleh petugas jika mengharapkan pasien terpuaskan

Secara matematik nilai probabilitas kualitas pelayanan, sarana prasarana dan lingkungan dapat memuaskan pasien atau pelanggan dapat dirumuskan dalam persamaan $\mathrm{y}=\mathrm{a}+$ $\mathrm{b} 1 \mathrm{x} 1+\mathrm{b} 2 \mathrm{x} 2+\mathrm{b} 3 \mathrm{x} 3$ atau $\mathrm{y}=20,611+$ $0,174 \mathrm{X}_{1}+0,784 \mathrm{X}_{2}+1,260 \mathrm{X}_{3}$. Artinya jika skor kualitas pelayanan, sarana parasarana dan lingkungan ditingkatkan misalnya diberikan skor 1 maka probability untuk 
meningkatkan skor kepuasan pelanggan sebesar $\mathrm{y}=20,611+0,174(1)+0,784(1)+$ 1,260 (1) atau y $=22.829$. Jika skor kualitas pelayanan, sarana prasarana dan lingkungan ditingkatkan menjadi skor 2 maka probability untuk meningkatkan skor kepuasan pelanggan sebesar y $=20,611+$ $0,174(2)+0,784(2)+1,260(2)$ atau $\mathrm{y}=$ 25.047 dan seterusnya.

\section{KESIMPULAN}

Hasil pengujian hipotesis yang pertama telah membuktikan ada pengaruh yang signifikan antara kualitas pelayanan terhadap kepuasan pasien di Puskesmas Pujon Kabupaten Malang ( $\phi$ value 0,002 < 0,05 maka Ho ditolak). Pengaruhnya bersifat positif artinya semakin tinggi skor kualitas pelayanan maka semakin tinggi skor kepuasan pasien dan sebaliknya.

Hasil pengujian hipotesis yang kedua telah membuktikan ada pengaruh yang signifikan antara sarana prasarana terhadap kepuasan pasien di Puskesdi Puskesmas Pujon Kabupaten Malang ( $p$ value $0,034<0,05$ maka Ho ditolak). Pengaruhnya bersifat positif artinya semakin tinggi skor sarana prasarana maka semakin tinggi skor kepuasan pasien dan sebaliknya.

Hasil pengujian hipotesis yang ketiga telah membuktikan ada pengaruh yang signifikan antara lingkungan terhadap kepuasan pasien di Puskesmas Pujon Kabupaten Malang ( $p$ value $0,034<0,05$ maka Ho ditolak). Pengaruhnya bersifat positif artinya semakin tinggi skor lingkungan maka semakin tinggi skor kepuasan pasien dan sebaliknya.

Hasil pengujian hipotesis yang keempat telah membuktikan ada pengaruh yang signifikan antara kualitas pelayanan, sarana prasarana dan lingkungan terhadap kepuasan pasien di Puskesmas Kabupaten Malang ( $p$ value $0,034<0,05$ maka Ho ditolak). Pengaruhnya bersifat positif artinya semakin tinggi skor kualitas pelayanan, sarana prasarana dan lingkungan maka semakin tinggi.

\section{SARAN}

Hasil pengujian determinasi atau adjusted $R$ square menjelaskan bahwa masih terdapat variabel lain yang mempengaruhi kepuasan pelanggan. Oleh sebab itu sebaiknya peneliti selanjutnya meneliti variabel lain yang belum diteliti seperti pengaruh kinerja petugas, kecepatan pelayanan terhadap kepuasan pasien.

\section{UCAPAN TERIMA KASIH}

Terimakasih kepada kepala Puskesmas serta responden yang telah berperan dalam terlaksananya penelitian ini. 
Care: Jurnal Ilmiah Ilmu Kesehatan Vol .7, No.2, 2019, hal 39-53

\section{REFERENSI}

Dinas Kesehatan Kabupaten Jombang. (2010). Profil Kesehatan Kabupate Jombang 2014. Jombang.

Kotler, P. (2000). Marketing Management.(Edisi Indonesia oleh HendraTeguh, Ronny dan Benjamin Molan). Jakarta: PT Indeks.

Tjiptono, F. dan G. C. (2005). Service, Quality, and Satisfactio. Yogyakarta: AndiOffset. 